\title{
Integrated flood forecasting and management system in a complex catchment area in the Alps-implementation of the MINERVE project in the Canton of Valais
}

\author{
J. García Hernández \& A. Claude \\ CREALP, Sion, Switzerland \\ J. Paredes Arquiola \\ $U P V$, Valence, Spain \\ B. Roquier \\ HydroCosmos S.A., Vernayaz, Switzerland \\ J.-L. Boillat \\ LCH, EPFL, Lausanne, Switzerland
}

\begin{abstract}
A complex hydrologic-hydraulic model has been developed for the Upper Rhone River basin in Switzerland. It is currently operational in the Canton of Valais for real-time flood forecasting and management, providing automatic warnings to the crisis cell of the Canton as well as proposing preventive emptying operations of dam reservoirs to reduce potential flood damage. The system is connected with a database for real-time data transfer and a website has been created to provide information for flood management, such as warning levels, hydrological forecasts at the main control points of the Rhône River and its tributaries, precipitation forecasts over the whole basin, snow cover state and reservoirs water levels. Besides, a hydrological call center has been established for supporting the crisis cell during risked event situations.
\end{abstract}

\section{INTRODUCTION}

\section{$1.1 \quad$ Framework}

The project of the Third Rhone Correction upstream from Lake Geneva improves the plain protection level during floods. In collaboration with this river engineering project, the MINERVE system (García Hernández et al. 2013; García Hernández 2011; Jordan 2007) aims to predict and optimize the management of flows using the hydrological forecasts and the hydropower scheme operation data. A model for hydro-meteorological forecasts coupled with a decision support system for preventive operating strategy of the hydropower plants have been developed and implemented.

\subsection{Objectives}

The objective of the operational system implemented in the Canton of Valais is to provide hydro-meteorological information to improve flood management in the Upper Rhone River basin. To achieve this task, a cluster for flood forecasting and management has been created at the Research Center on Alpine Environment (CREALP). This multidisciplinary group is operating a real-time flood forecast system that provides hydrological forecasts with the RS MINERVE tool (chapter 4.2) at the main control points of the Rhone River and its tributaries. Based on the hydrological forecasts, automatic warnings, associated with four 
different thresholds at each control point, are provided to the crisis cell. Finally and also based on these forecasts, preventive operations can be proposed to hydropower schemes owners to reduce as much as possible the potential flood damages.

\section{UPPER RHONE BASIN}

\subsection{The basin}

The Upper Rhone River basin (Fig. 1) is located in the Swiss Alps, upstream from Lake Geneva. It covers a surface of $5,524 \mathrm{~km}^{2}$, including $658 \mathrm{~km}^{2}$ of glaciers, and is characterized by high mountains with elevations varying from 372 to 4'634 m a.s.1.

The total length of the Rhone River, from its source at the Rhone Glacier over 2'200 m a.s.1. to the Lake of Geneva at $372 \mathrm{~m}$ a.s.1., is around $165 \mathrm{~km}$. The average year discharge between January 1st 1980 and January 1st 2014 at Porte du Scex, outlet of the basin, was $189 \mathrm{~m}^{3} / \mathrm{s}$, and the highest discharge 1'358 m³/s, measured on October 15th, 2000.

Many hydropower schemes with large reservoirs are located in the watershed, strongly influencing the hydrological regime of the river network. The reservoirs have a total storage capacity of 1'195 Mio $\mathrm{m}^{3}$ and a total equipped discharge of more than $500 \mathrm{~m}^{3} / \mathrm{s}$.

\subsection{Spatial discretization of the basin}

The watershed (Fig. 1) has been divided into 245 sub-basins taking into account not only the Digital Elevation Model (DEM), but also the gauging stations and rivers junctions as well as reservoirs, hydropower plants and intakes. Each sub-basin was next discretized into different elevation bands allowing temperature adjustment. The model also takes into account the glacial cover with the last available data of swissTLM3D, being the 1347 defined elevation bands distributed into non-glacial (1027) and glacial (320). For the non-glacial bands, the average surface is $4.7 \mathrm{~km}^{2}$ and the average of the vertical altitude difference of each band is

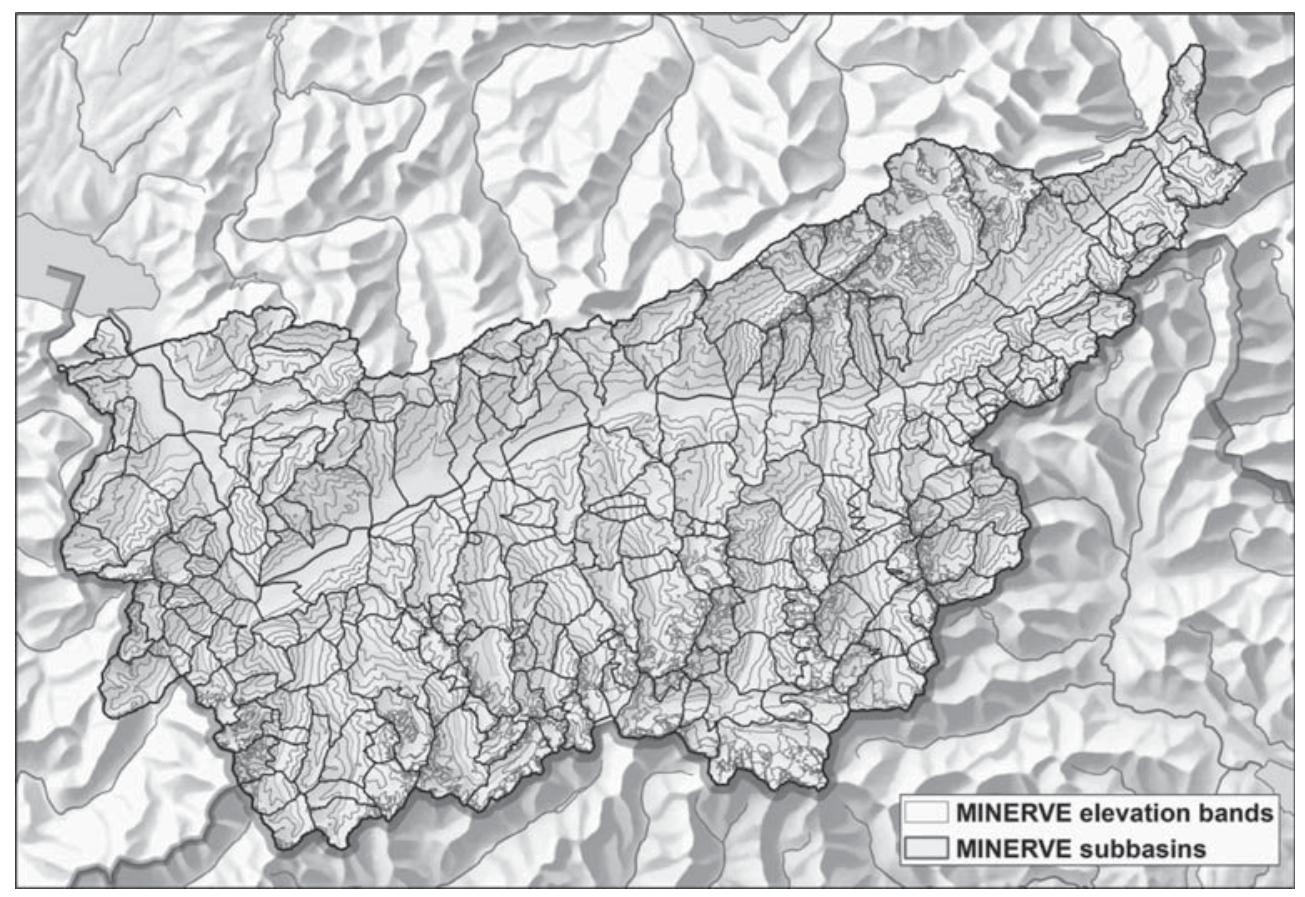

Figure 1. Upper Rhone River basin with its 245 sub-basins and 1347 altitude bands. 
$361 \mathrm{~m}$. For the glacial bands, the average surface is $2.1 \mathrm{~km}^{2}$ and the average vertical space $327 \mathrm{~m}$.

The Rhone River has been divided into 22 river reaches and the tributaries still bring 141 additional river segments to complete the hydrological model.

Finally, significant storage reservoirs (14), compensating basins (13), hydropower plants (31) and intakes (91) have been included in the model.

\subsection{Hydrological model}

Based on the spatial discretization of the basin, a semi-distributed model was developed to simulate the hydrological and hydraulic behavior of the river basin. The model includes snow-melt, glacier melt, soil infiltration, surface runoff, flood routing in rivers and reservoirs as well as hydropower plants operations.

To take into account the hydrological processes, different hydrological models to calculate rainfall-runoff processes are provided by the RS MINERVE numerical tool (chapter 4.2).

The GSM (Glacier and SnowMelt) model (Schäfli et al. 2005) calculates the snow and glacier melts with a degree-day approach. The new SOCONT (Soil Contribution) model includes a snow model, a GR3 model (Michel and Edijatno 1988; Consuegra et al. 1998) calculating infiltration and a SWMM (Storm Water Management Model) model (Metcalf and Eddy, 1971) for runoff simulation.

The model HBV (Bergström 1976, 1992) is an integrated rainfall-runoff model, which includes conceptual numerical descriptions of hydrological processes at the catchment scale. It also calculates the snow processes as well as runoff and slow and rapid infiltration flows.

The GR4 J model is a hydrological model (Perrin et al. 2003) which simulates the flow from a production and a routing stores based on two unit hydrographs.

Finally, the SAC-SMA (Sacramento Soil Moisture Accounting Model) model (Burnash et al. 1973; Burnash 1995) calculates the runoff and the baseflow distinguishing different soil zones, with rational percolation characteristics.

Based on the concept of the elevation bands per sub-basin, the model was built from upstream as presented in Figure 2. The elevation bands of each sub-basin supplies the same outlet. Then, the discharge flows through a river reach to the next junction, where contributions from other different sub-basins can be added.

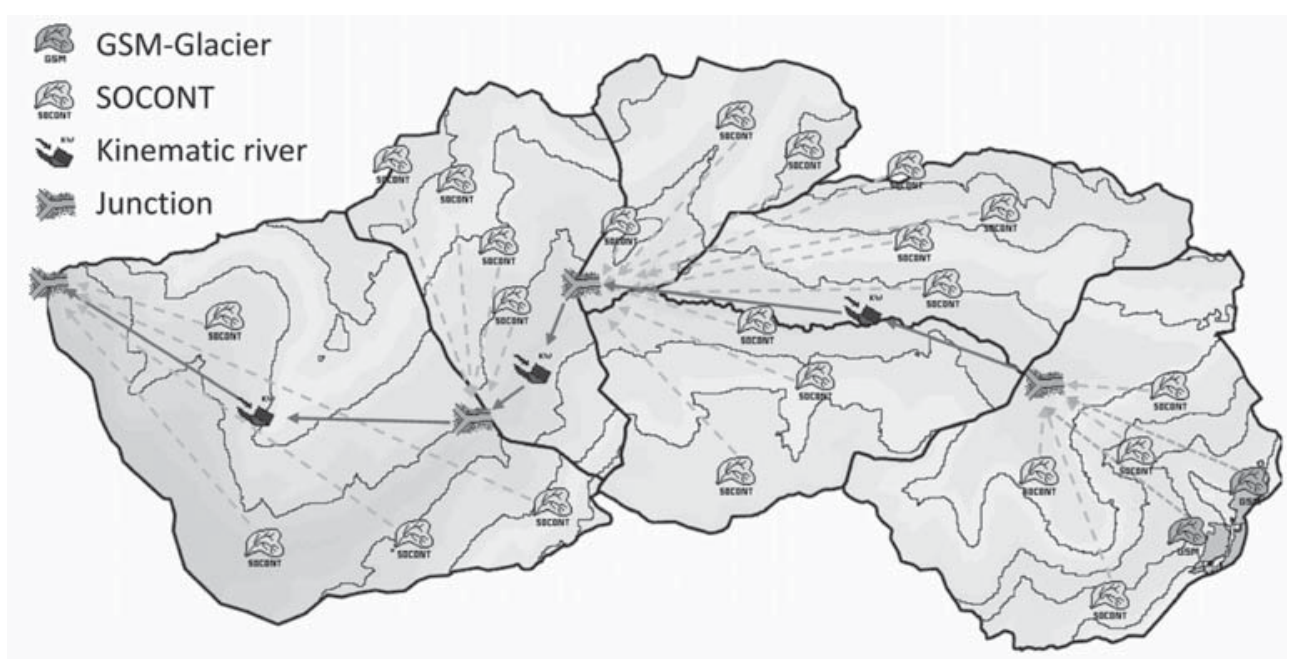

Figure 2. Sub-basins and elevation bands in the Grande Eau watershed (tributary in the downstream part of the Upper Rhone River basin) and their schematic representation as glacier and non-glacier bands, rivers and junctions. 
Potential Evapotranspiration (PET) can be provided by the database if available. Since only precipitation and temperature values are available at this moment, different methods have been implemented in RS MINERVE for PET estimation. Turc $(1955,1961)$ equation as well as McGuinness and Bordne (1972) calculate PET based on current temperature and global radiation. Oudin (2004) methodology provides PET values based on current temperature and estimated extraterrestrial radiation.

The value of global radiation $\mathrm{R}_{\mathrm{g}}$ is calculated per month (average value) depending on the latitude and longitude of the river basin and is based on 22 years monthly averaged (July 1983-June 2005). These $\mathrm{R}_{\mathrm{g}}$ data were obtained from the NASA Langley Research Center Atmospheric Science Data Center Surface meteorological and Solar Energy (SSE) web portal supported by the NASA LaRC POWER Project (http://eosweb.larc.nasa.gov/sse/).

\section{HYDRO-METEOROLOGICAL INPUTS}

\subsection{Meteorological data}

Meteorological observed values are provided by MeteoSwiss (31stations) and SLF (52 stations) networks (Fig. 3), respectively at a ten and thirty minutes time step. The MeteoSwiss stations provide precipitation, temperature, wind (speed and direction) and relative humidity data and are located at altitudes between 380 and 2'500 meters (mean of 1'700 meters). The SLF stations provide, depending on each station, values such as precipitation, temperature, snow height, wind direction and intensity or humidity. They are mainly installed for avalanche risk evaluation, delivering a good representation of the high relief meteorological variability, at altitudes between 2'000 and 3'300 meters (mean of 2'662 meters).

For the computation of flood predictions, the meteorological forecast model COSMO-7, provided by MeteoSwiss, is available. It is driven by the global model ECMWF (European Centre for Medium-Range Weather Forecasts) and covers most of Western and Central

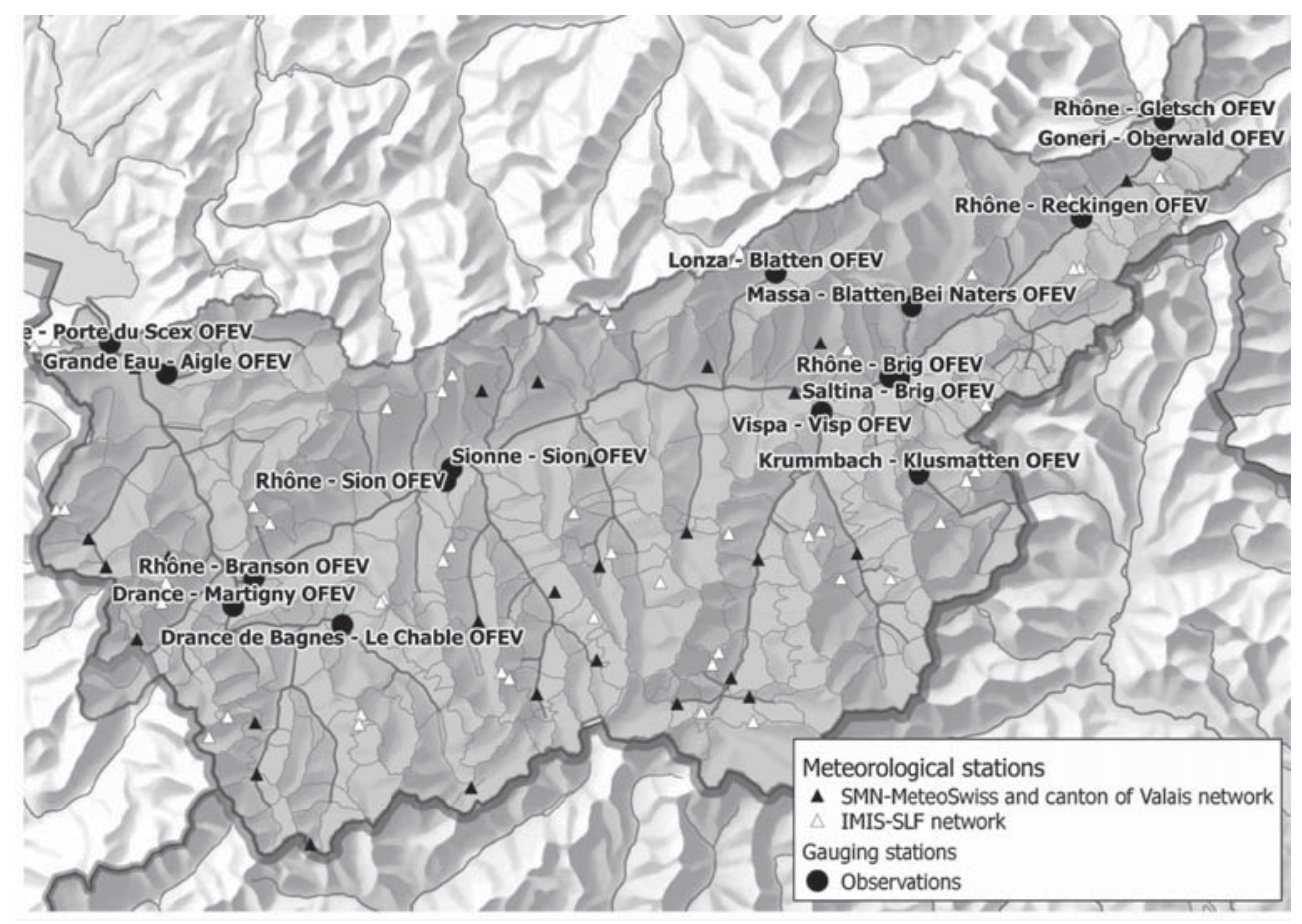

Figure 3. Hydro-meteorological data available in real-time in the Upper Rhone River basin. 
Europe. Its spatial resolution is $6.6 \mathrm{~km}$ and the temporal resolution is $1 \mathrm{~h}$. The horizon is $72 \mathrm{~h}$ and it is updated three times a day at 00:00, 06:00 and 12:00 UTC.

\subsection{Hydrological data}

Gauging stations are mainly operated by the Federal Office for the Environment (FOEN). Discharge series in 17 FOEN stations located in the basin are available since more than 30 years ago and are nowadays obtained in real-time (Fig. 3) each 10 minutes or 1 hour depending on the stations.

In addition, 6 cantonal stations measuring water levels are also available in real-time since 2013 in some Rhone tributaries, but they are not yet used in the operational system. Their relationship between level and discharge is being currently calculated and will allow improving the model results by providing additional control points for calibration. Furthermore, other cantonal stations will be installed in 2014 in other tributaries and will also improve the model performance, especially for the concerned lateral valleys.

\subsection{Snow data}

To calculate the snow cover, a processing for MODIS (Moderate Resolution Imaging Spectroradiometer) data was developed to obtain observed snow extent and its evolution. This information is later used for updating the snow cover considered in the hydrological model.

The MODIS data are produced by an imaging radiometer for Aqua and Terra satellites. Both satellites are part of the EOS program (Earth Observing System) from the NASA. The CREALP uses cryosphere data (snow and ice on land) from MODIS, which are freely available on the National Snow and Ice Data Center website. The evolution of the snow cover and land can then be observed and studied. The snow cover is calculated once per day, with an average delay of two or three days (Fig. 4). In addition, historical data since February 2000 are available and allow calculating the snow cover norm per day or per month (Fig. 5).

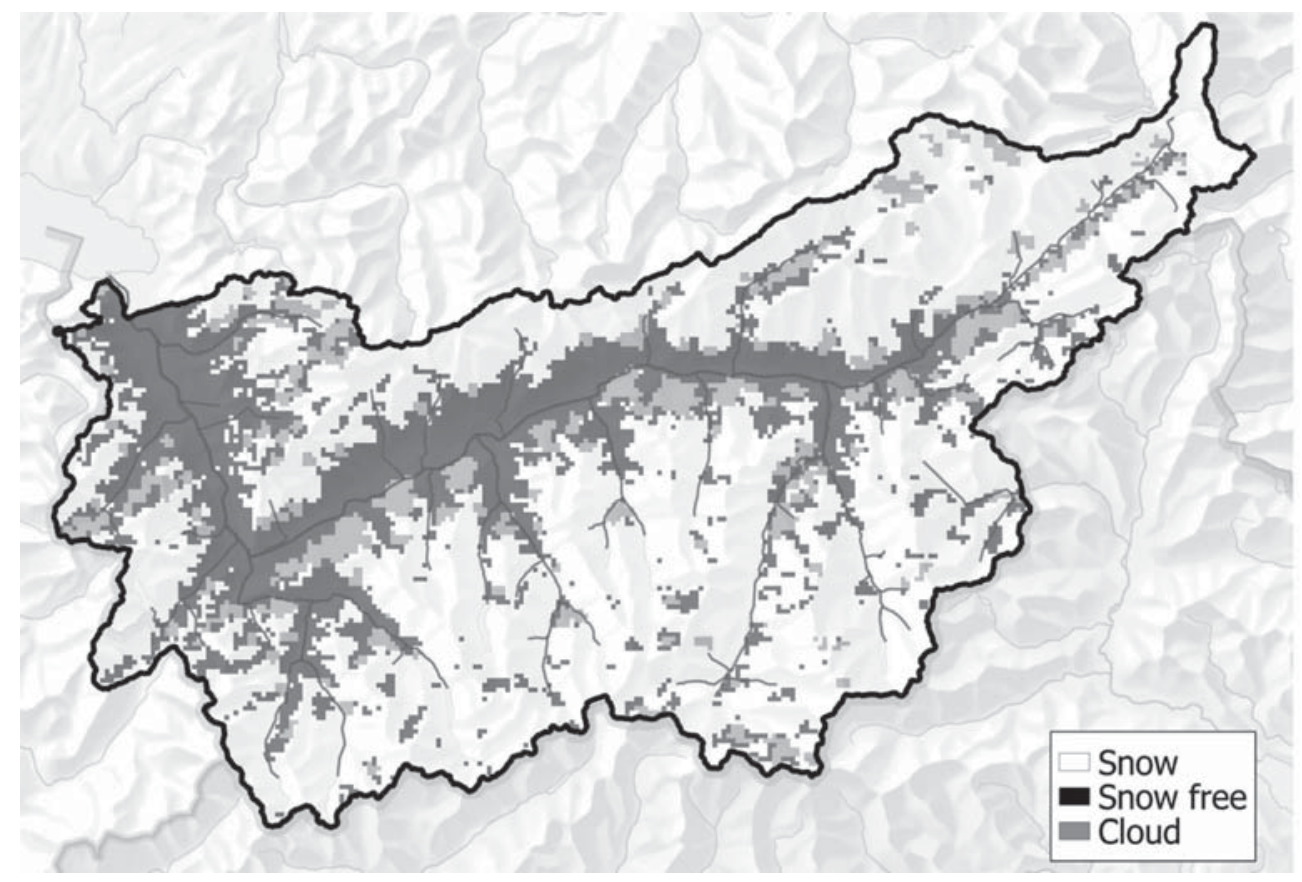

Figure 4. Snow cover from MODIS on January 12th, 2014. 


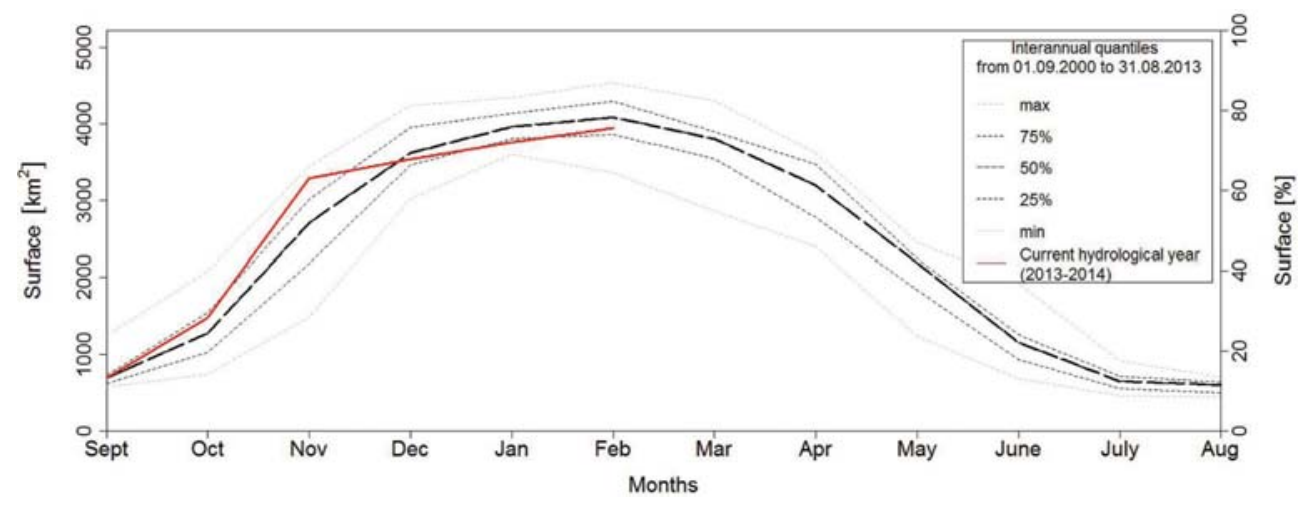

Figure 5. Quartiles 0, 25, 50, 75 and 100\% with the snow cover of the Upper Rhone River basin calculated with MODIS data from 01.09.2000 to 31.08.2013, as well as the current situation from September 2013 to February 2014.

\section{OPERATIONAL SYSTEM}

\subsection{Operational scheme}

The implemented real-time flood forecasting system (Fig. 6) is composed of: a database for hydro-meteorological data storage and real-time data transfer; a computer for automatic hydrological simulation (hindcasting with observed meteorological values and forecasting with meteorological forecasts); and a website for hydro-meteorological data information, where observations and forecasts are presented through graphics and tables.

The database stores all hydro-meteorological information that it receipts from the different providers. Afterwards, meteorological (precipitation and temperature observations and forecasts) and hydrological (discharge measurements) data are sent to the computer dedicated to hydrological calculations. The hydrological simulations are realized with the aid of the tool RS Pilot (chapter 4.3), which manages the hydrologic-hydraulic software RS MINERVE.

The hydrological outputs (discharge forecasts at main control points) are sent to the database to be stored. Then, data are transmitted and published in the information website polhydro.ch. This one has been created with the objective of displaying all useful information for managing floods, such as warning levels, hydrological forecasts at main control points of the Rhone River and its tributaries, precipitation forecasts over the whole basin, snow cover state and reservoirs water levels, among other information.

\subsection{Hydrological/hydraulic simulations with RS MINERVE}

Routing System II (Dubois and Boillat 2000; García Hernández et al. 2007), was developed at the Laboratory of Hydraulic Constructions ( $\mathrm{LCH}$ ) at the Ecole Polytechnique Fédérale de Lausanne (EPFL). This program simulates the free surface run-off and its propagation. It models hydrological and hydraulic complex networks according to a semi-distributed conceptual scheme. In addition to particular hydrologic processes (snowmelt, glacier melt, surface and underground flow), hydraulic control elements (e.g. gates, spillways, diversions, junctions, turbines and pumps) can be also incorporated.

Built upon Routing System II, RS MINERVE (Foehn et al. 2014; García Hernández et al. 2014) was almost completely recoded to obtain a program that is both efficient and userfriendly for hydrological and hydraulic modeling.

The global analysis of a hydrologic-hydraulic network is essential for the development and optimization of an appropriate flood protection concept or the potential role of hydropower plants. RS MINERVE (Fig. 7) allows such kind of analysis due to its simple and intuitive interface and its open structure facilitates the implementation and adaptation of 


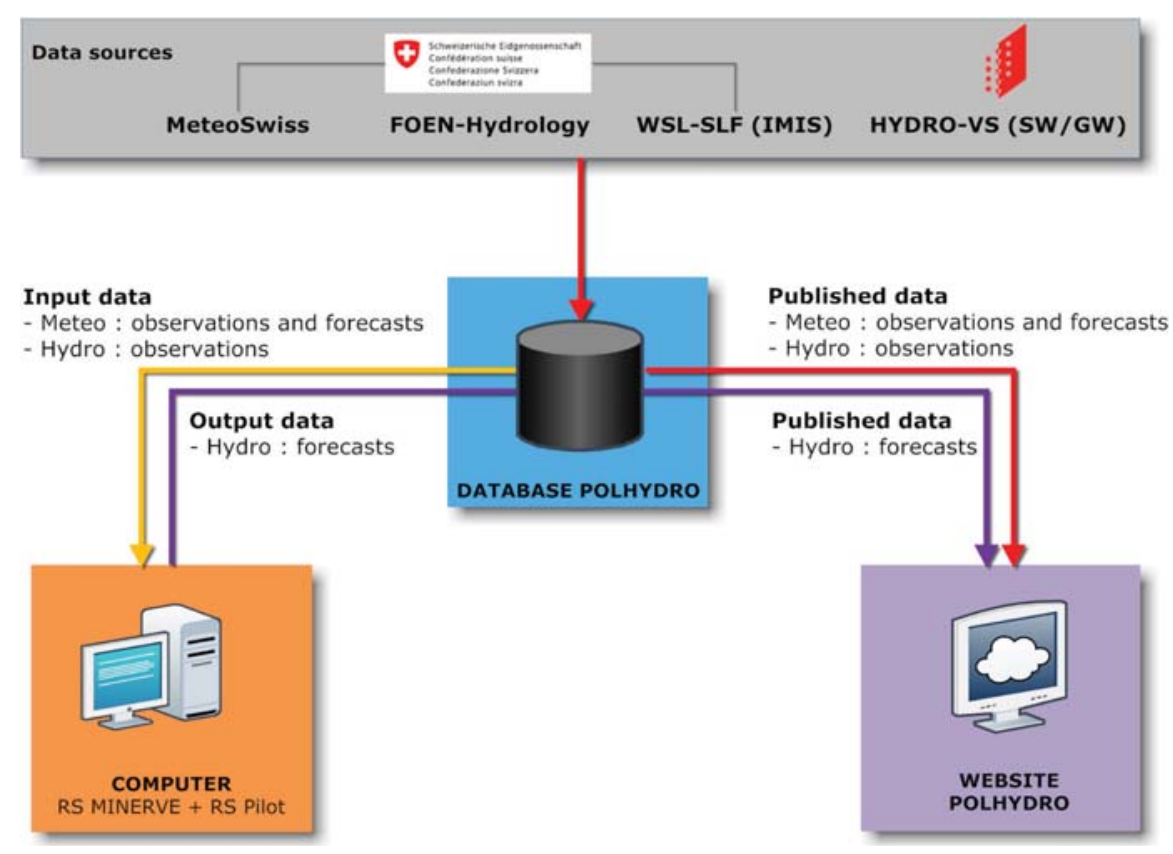

Figure 6. Operation of the RS MINERVE system for flood forecasting in the Canton of Valais.

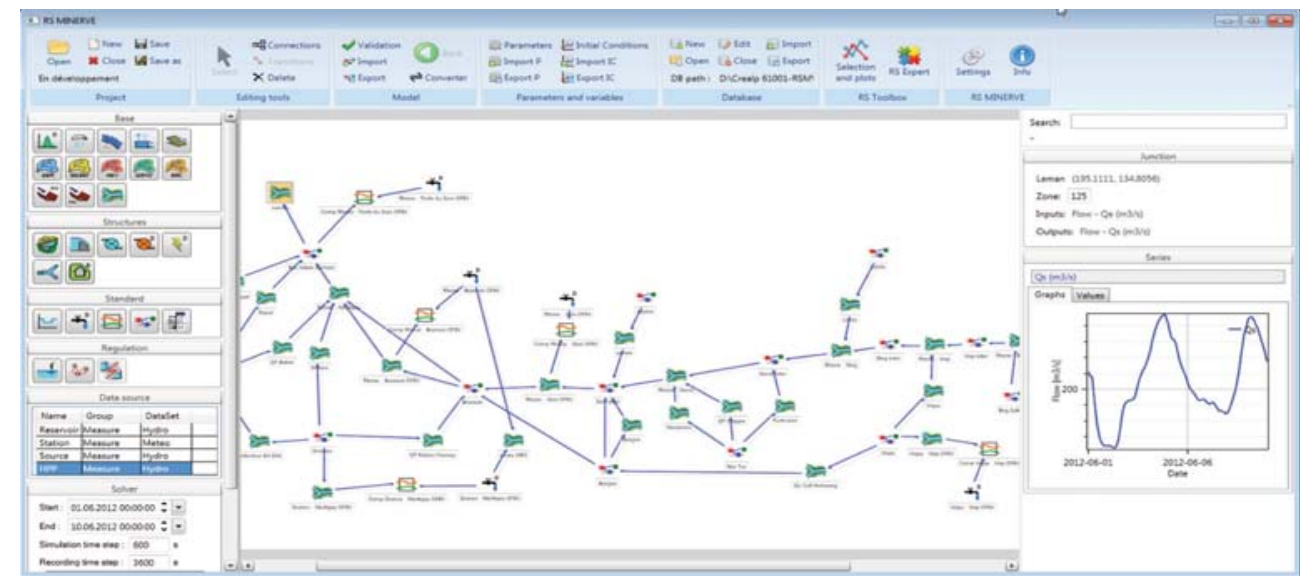

Figure 7. RS MINERVE main interface.

new developments. The implementation of an RS Expert section, with 3 modules detailed hereafter, allows easily improving the model performance and better evaluating hydrologic and hydraulic results.

The automatic calibration module, with the SCE-UA algorithm (Duan et al., 1992, 1993, 1994), calculates the best set of hydrological parameters depending on an objective function defined by the user and becomes a key element of the software. This new module is being currently used for improving the model performance based on different criteria such as Nash Coefficient, Relative Volume Bias or Pearson Correlation.

The second module for time-slice simulations facilitates the analysis of large data sets without overloading the computer memory. It allows the evaluation of the model results performance over the whole Rhone river basin for the complete database, calculating it year by year. 
The third module for scenario simulations introduces the possibility of simulating multiple weather scenarios or several sets of parameters and initial conditions to evaluate the variability and sensitivity of the model results. It is useful in flood situations for providing additional information about the situation and assessing the uncertainty of the forecast and/ or the model.

Finally, data assimilation is used to improve the results obtained with RS MINERVE since the beginning of 2014. The procedure is currently manual and the assimilation is undertaken once the performance of the model is not satisfactory.

Discharge series at 17 measurements points in the basin are used for updating the model and the saturation balance is modified to achieve enhanced discharge values. Furthermore, snow cover (MODIS) is applied to adjust the snow model extent considered by the hydrological model and provide reliable flow from snow melt. Finally, the available levels of reservoirs are also used to update the model, starting each new simulation from the correct reservoir level.

\subsection{RS pilot}

RS Pilot was developed to perform automatic simulations with RS MINERVE. To achieve this goal, a timetable is defined beforehand, which contains the time at which the system imports the meteorological forecast, runs the model and exports the hydrological results.

To perform hydrological forecasts, two different tasks are managed by RS Pilot. On one hand, the "Control simulation" task allows running the hydrological simulation with the last meteorological observations to get the hydrological state variables, such as snow height or soil saturation. On the other hand, the "Forecast simulation" task takes into account the last meteorological forecast and the hydrological state variables obtained by the previous task.

\subsection{Operational center of hydro-meteorological monitoring}

A hydro-meteorological call center has been established to support the crisis cell of the Canton of Valais during critical events. A pool of operators was created and trained on the different meteorological and hydrological tools to be able to ensure the hydro-meteorological monitoring. This call center provides an important scientific and technical support for the flood risk management.

The supervision is mainly based on the data monitoring. On one hand, data such as current and previous rainfall, temperature or snow cover per sub-basin or discharge at the main control points are checked. On the other hand, meteorological forecast provided by MeteoSwiss are analyzed at the same time as the hydrological forecasts at the main control points.

The hydrological flow forecasts are computed at each sub-basin of the model. Among them, 23 control points (Fig. 8), corresponding to the gauging stations (for comparison reasons) and to sensitive locations like confluences or bridges, are presented in the website polhydro.ch.

Depending on the precipitation, MeteoSwiss proposes several danger levels from 1 (no or minor danger) to 5 (very high danger) on 23 regions over the Rhone River basin. In addition, 4 of the control points located on the Rhone River are used to indicate the same danger levels ( 1 to 5 ) depending on different discharge thresholds provided by the Canton of Valais.

Contacts with the Geneva MeteoSwiss forecasters are established when the meteorological situation deserves further information. Other contacts and information exchange with the Department for Roads, Transports and Watercourses of the Canton of Valais as well as with the Swiss Federal Office for Environment (FOEV) are also maintained when discharge values go near the second threshold (third danger level).

The website polhydro.ch provides latest hydro-meteorological information to the operators following the situation as well as to the crisis cell of the Canton of Valais for taking possible measures (structural protection measures, information to the population, village evacuation, etc). An automatic report with an overview of the current available information is also sent daily by mail to the concerned people and can be updated if required. 


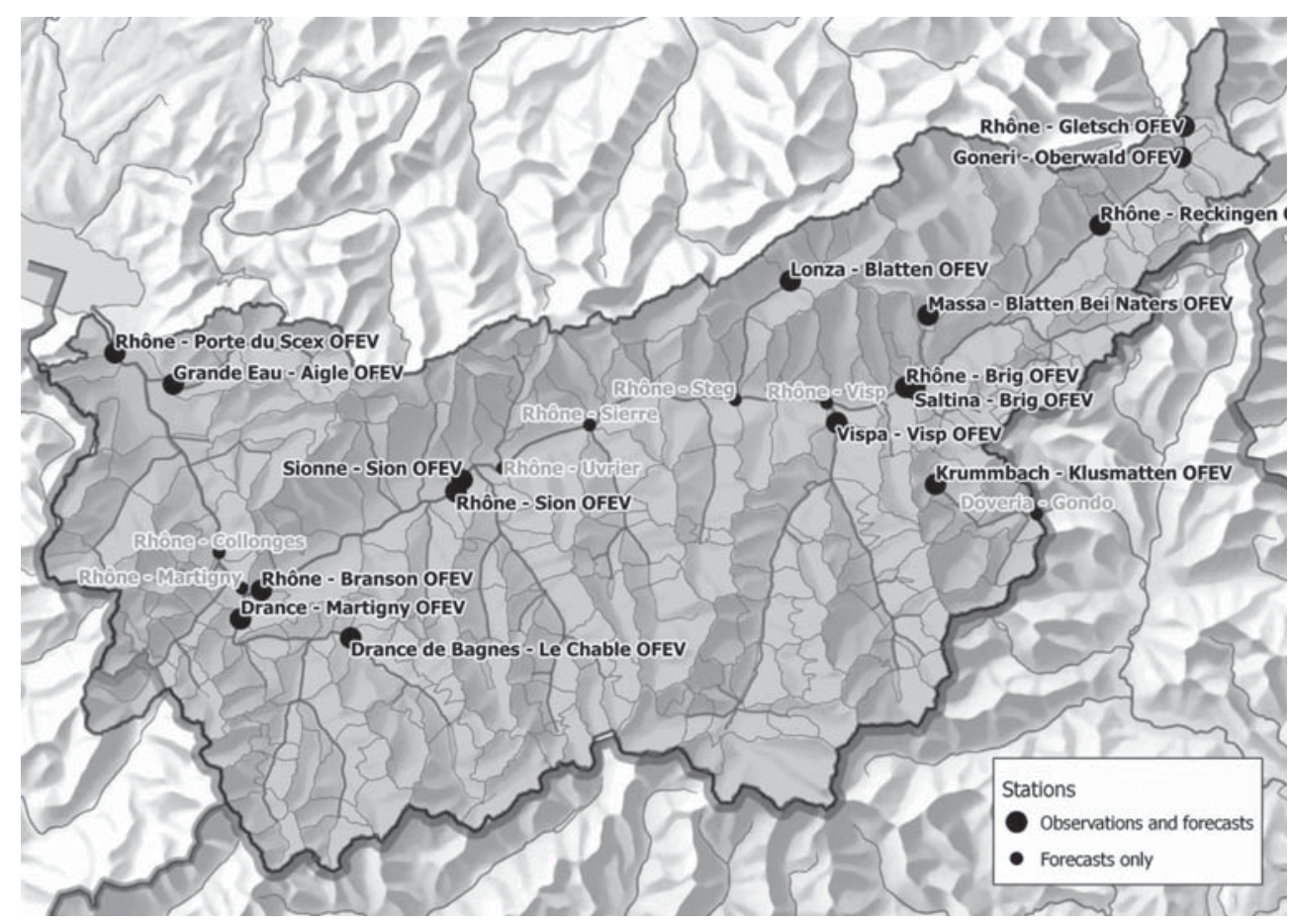

Figure 8. Hydrological control points with discharge forecasts.

\section{HYDROLOGICAL FORECASTS}

The MINERVE system provides 3 hydrological forecasts per day (00:00, 06:00 and 12:00 UTC) based on COSMO-7 meteorological forecasts. Precipitation and temperature are used as input of the hydrological model. Potential evapotranspiration is calculated from the Turc $(1955,1961)$ method and hydropower operations are estimated beforehand based on turbining scenario.

The system, operational from the beginning of 2013, provides warnings for 4 thresholds in 4 control points located on the Rhone River. An overview of the warnings performance for the first threshold during the 2013 year is presented hereafter at these 4 control points (Fig. 9). The performance of the warning system is continuously monitored and each warning is sorted as a Hit, a Miss or a False alarm. A Hit is recorded if observation and forecast exceed the threshold for a given day; if only the observation exceeds the threshold, a Miss is registered; and finally when only the forecast exceeds the threshold, a False Alarm is considered.

The results show a low performance for the control point of Brig (threshold T1 $=250 \mathrm{~m}^{3} / \mathrm{s}$ ), due to overestimations of the snow coverage and the precipitation forecast. At control points of Sion $\left(\mathrm{T} 1=460 \mathrm{~m}^{3} / \mathrm{s}\right)$ and Branson $\left(\mathrm{T} 1=470 \mathrm{~m}^{3} / \mathrm{s}\right)$, results were more compelling although several false alarms were noticed due to an overestimation of the precipitation. At the outlet of the basin, Porte-du-Scex $\left(\mathrm{T} 1=700 \mathrm{~m}^{3} / \mathrm{s}\right.$ ), results gave some miss events due to underestimated precipitation forecasts over the lower part of the basin and small saturation of the soil, as well as one false alarm due to a too high snow cover.

In 2014, the revision of the initial conditions of the hydrological model based on MODIS snow cover and discharge data from gauging stations improves hydrological forecasts and, then, the reliability of the warning system. In addition, new cantonal gauging stations provide data to recalibrate the entire model. 


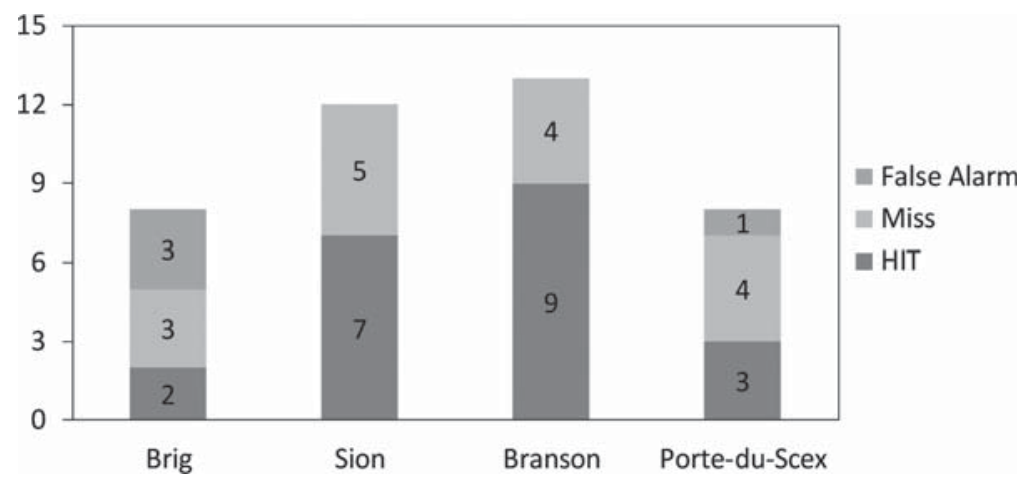

Figure 9. Hit, Miss and False Alarm results for Brig, Sion, Branson and Porte-du-Scex in 2013.

\section{CONCLUSIONS}

The MINERVE system is integrated in the cantonal procedure for the Rhone River flood management. It allows simulating the discharge in the river network of the Upper Rhone catchment area since it considers all hydropower plants and dams, turbine operations and water releases.

The objective of the system is to establish an optimal coordination of actions to reduce the risk of flooding taking into account present and future hydro-meteorological situation over the whole basin (Rhone River and its tributaries). The approach is based on exploitation and monitoring of observed data as well as on hydro-meteorological forecasts. The system provides the useful information to the cantonal decision-making crisis cell, which determines the level of danger and triggers appropriate protective measures or interventions.

With a constant concern for consolidation and improvement, the MINERVE system continuously modernizes its operational environment at the same time that hydrological and hydraulic issues are studied and carried out for improving the performance of the system and decreasing its uncertainty.

\section{REFERENCES}

Bergström, S. 1976. Development and application of a conceptual runoff model for Scandinavian catchments. Ph.D. Thesis. SMHI Reports RHO No. 7, Norrköping.

Bergström, S. 1992. The HBV model-its structure and applications. SMHI Reports RH, No. 4, Norrköping.

Burnash, R.J.C., Ferral, R.L., and McGuire, R.A. 1973. A generalized streamflow simulation systemConceptual modelling for digital computers. US Department of Commerce, National Weather Service and State of California, Department of Water Resources, p 204, 1973.

Burnash, R.J.C. (1995). The NWS River Forecast System — catchment modeling. In: Singh, V.P. (Ed.). Computer Models of Watershed Hydrology, 311-366.

Consuegra D., Niggli M. and Musy A. 1998. Concepts méthodologiques pour le calcul des crues. Application au bassin versant supérieur du Rhône. Wasser, Energie, Luft—eau, énergie, air, Heft 9/10, 223-231.

Duan, Q., Gupta, V.K. and Sorooshian, S. 1993. A shuffled complex evolution approach for effective and efficient global minimization. Journal of Optimization Theory and Applications, Vol. 76, 501-521.

Duan, Q., Sorooshian, S. and Gupta, V. 1992. Effective and Efficient Global Optimization for Conceptual Rainfall-Runoff Models. Water Resources Management, Vol. 28, 1015-1031.

Duan, Q., Sorooshian, S. and Gupta, V.K. 1994. Optimal use of SCE-UA global optimization method for calibrating watershed models. Journal of Hydrology, Vol. 158, 265-284.

Dubois, J. and Boillat, J.-L. 2000. Routing System-Modélisation du routage des crues dans des systèmes hydrauliques à surface libre. Communication 9 du Laboratoire de Constructions Hydrauliques, Ed. A. Schleiss, Lausanne. 
Foehn, A., García Hernández, J., Claude, A., Roquier, B., Paredes Arquiola, J. and Boillat, J.-L. 2014. RS MINERVE—User's manual v1.9. RS MINERVE Group, Switzerland.

García Hernández, J. 2011. Flood management in a complex river basin with a real-time decision support system based on hydrological forecasts. PhD Thesis $N^{\circ} 5093$, Ecole Polytechnique Fédérale de Lausanne, EPFL, Switzerland, and Communication 48 du Laboratoire de Constructions Hydrauliques, Ed. A. Schleiss, EPFL, Lausanne.

García Hernández, J., Boillat, J.-L., Feller, I. \& Schleiss A.J. 2013. Présent et futur des prévisions hydrologiques pour la gestion des crues. Le cas du Rhône alpin. Mémoire de la Société vaudoise des Sciences naturelles 25: 55-70. ISSN 0037-9611.

García Hernández, J., Jordan, F., Dubois, J. and Boillat, J.-L. 2007. Routing System II: Flow modelling in hydraulic systems. Communication 32 du Laboratoire de Constructions Hydrauliques, Ed. A. Schleiss, EPFL, Lausanne.

García Hernández, J., Paredes Arquiola, J., Foehn, A., Claude, A., Roquier, B. and Boillat, J.-L. 2014. RS MINERVE-Technical manual v 1.6. RS MINERVE Group, Switzerland.

Jordan, F. 2007. Modèle de prévision et de gestion des crues - optimisation des opérations des aménagements hydroélectriques à accumulation pour la réduction des débits de crue. PhD Thesis $N^{\circ} 3711$, Ecole Polytechnique Fédérale de Lausanne, EPFL, Switzerland,; and Communication 29 du Laboratoire de Constructions Hydrauliques, Ed. A. Schleiss, EPFL, Lausanne.

McGuinness, J.L. and Bordne, E.F. 1972. A comparison of lysimeter-derived potential evapotranspiration with computed values. Technical Bulletin 1452, Agricultural Research Service, U.S. Department of Agriculture, Washington D.C., 71 pp.

Metcalf and Eddy, Inc., University of Florida, and Water Resources Engineers, Inc. 1971. Storm Water Management Model, Vol. I. Final Report, 11024DOC07/71 (NTIS PB-203289), U.S. EPA, Washington, DC, 20460.

Michel, C. and Edijatno 1988. Réflexion sur la mise au point d'un modèle pluie-débit simplifié sur plusieurs bassins versants représentatifs et expérimentaux. CEMAGREF Antony.

Oudin, L. 2004. Recherche d'un modèle d'évapotranspiration potentielle pertinent comme entrée d'un modèle pluie-débit global. Thèse, Ecole Nationale du Génie Rural, des Eaux et des Forêts, Paris.

Perrin, C., Michel, C. and Andréassian, V. 2003. Improvement of a parsimonious model for streamflow simulation. Journal of Hydrology 279, 275-289.

Schäfli, B., Hingray, B., Niggli, M. and Musy, A. 2005. A conceptual glacio-hydrological model for high mountainous catchments. Hydrology and Earth System Sciences Discussions 2, 73-117.

Turc, L. 1955. Le bilan de l'eau des sols. Relations entre les precipitations, l'evaporation et l'ecoulement. Ann. Agro. 6, 5-152, INRA.

Turc, L. 1961. Evaluation des besoins en eau d'irrigation, formule climatique simplifiée et mise à jour. Ann. Agro. 12: 13-49, INRA. 